\title{
Subject Removed at Sponsor Request
}

National Cancer Institute

\section{Source}

National Cancer Institute. Subject Removed at Sponsor Request. NCI Thesaurus. Code C161410.

An indication that the study subject was removed from the study at the sponsor's request. 